\title{
PEDAGOGICAL PRINCIPLES OF YEVHEN STANKOVYCH
}

УДК 37.013.2+781.61

DOI https://doi.org/10.32843/26636085/2021/33-2.7

\section{Регеша Н.Л.,}

заслужений діяч мистецтв України, доцент кафедри музичного мистецтва Київського національного університету культури і мистецтв

\section{Скопцова О.М.,}

канд. мистецтвознавства, доцент кафедри музичного мистецтва Київського національного університету культури і мистецтв

\begin{abstract}
У статті виділено базові педагогічні принципи провідного українського композитора Євгена Федоровича Станковича. Маситаб його творчості є чималим, адже охоплює широкий спектр творів, серед якихє опера, балети, симфонії, концерти, вокально-симфонічні твори та музика до кінострічок. Його творчий і педагогічний шлях нерозривно пов'язані. Власні композиторські напрацювання Євгена Станковича впливають на формування тенденцій в українській музиці. Вони сприяють вихованню певної слухацької культури, призвичаюючи глядачів до сприйняття сучасного композиторського мислення.
\end{abstract}

Євген Станкович є універсальним митцем, який задає нові параметри для творчого розвитку національної композиторської школи. Будучи учнем провідного композитора-класика української музичної культури Бориса Лятошинського, Євген Федорович успадкував від нього інтерес до жанрового різноманіття, пошуковий характер творчості, що реалізується через різні техніки композиції. Залежно від обраного жанру композитор диференціює виразні засоби, намагаючись дотримуватися кореляції між фрункціональним призначенням твору та шляхами досягнення художньої мети. Інтонаційний бік його музики тісно пов'язаний із фоольклорним мелосом. Плюралізм і відсутність обмеження свободи творчості учнів є основними методичними принципами Станковича. За допомогою таких підходів $і$ ссрормувалася творча майстерність учнів мития.

Його учнями були Людмила Юріна, Сергій Зажитько, Дмитро щириця, Золтан Алмаші, Анна Рождественська та інші провідні композитори. Колишні учні його класу мають різний творчий почерк. Не можна виділити єдину магістральну лінію розвитку майстерності випускників класу Євгена Станковича, адже композитори працюють у різних напрямах - від неоромантизму $і$ неофольклоризму до джазу, року та перформативних практик. Подібна широта уподобань сфоормована завдяки плюралізму педагогічного підходу Євгена Станковича у викладацькій справі та підтримці талановитої молоді.

Ключові слова: композитор, педагог, методичні принципи, Євген Станкович, плюралізм.
The article highlights the basic pedagogical principles of the leading Ukrainian composer Yevhen Fedorovych Stankovych. The scale of his work is considerable, as it covers a wide range of works, including opera, ballets, symphonies, concerts, vocal-symphonic works and music for films. His creative and pedagogical path is inextricably linked. Yevhen Stankovych's own composing works influence the formation of trends in Ukrainian music. They contribute to the education of a certain listening culture, accustoming the audience to the perception of modern compositional thinking.

Yevhen Stankovych is a universal artist who sets new parameters for the creative development of the national school of composition. As a student of the leading composer-classic of Ukrainian musical culture Borys Lyatoshynsky, Yevhen Fedorovych inherited from him an interest in genre diversity, the exploratory nature of creativity, which is realized through various techniques of composition. Depending on the chosen genre, the composer differentiates expressive means, trying to adhere to the correlation between the functional purpose of the work and the ways to achieve the artistic goal. The intonation of his music is closely connected with folk melody. Pluralism and the absence of restrictions on the freedom of creativity of students are the main methodological principles of Stankovych.

With the help of such approaches the creative skill of Yevhen Stankovych's students was formed. His students were Lyudmila Yurina, Serhiy Zazhytko, Dmytro Shchyrytsia, Zoltan Almashi, Anna Rozhdestvenska and a number of other leading composers. Former students of his class have different creative handwriting. It is impossible to single out a single main line of development of skills of graduates of E. Stankovych's class, because composers work in different directions from neo-romanticism and neo-folklore to jazz, rock and performative practices. Such a breadth of preferences is formed due to the pluralism of Yevhen Stankovych's pedagogical approach in teaching and support of talented youth.

Key words: composer, teacher, methodical principles, Yevhen Stankovych, pluralism.
Постановка проблеми в загальному вигляді. Серед українських композиторів сьогодення провідне місце займає Євген Станкович. Його внесок у розвиток української музичної культури є надзвичайно великим. Композиторська справа, в якій він зарекомендував себе як високопрофесійний майстер, сполучається 3 іншими фрормами діяльності митця. Зокрема, мало уваги приділено питанню його здобутків на педагогічній ниві та впливу на розвиток сучасної композиторської школи. Він виступає продовжувачем традицій провідних композиторів, виховав чимало авторів, які працюють у різних стильових напрямах і техніках. Євген Станкович є одним із фундаторів нефольклорних тенденцій в українській композиторській школі, що вплинуло на відродження інтересу до народнопісенної творчості українського народу. Варто виокремити ті риси, які характеризують педагогічні принципи Євгена Станковича. 
Аналіз останніх досліджень і публікацій. Стильові особливості творів $€$. Станковича досліджувались у низці робіт сучасних авторів. Зокрема, жанрово-виконавські аспекти хорового стилю композитора аналізувала А. Волотка. Загальні риси творчих напрацювань Станковича окреслювалися у публікаціях А. Луніної та Ю. Чекана. Питання, що стосуються фрілософії творчості композитора, потребують звернення до праць мислителя П. Сорокіна та критичної літератури, яка стосується осмислення його спадку. Серед масиву робіт, присвячених цій тематиці, доречно згадати статтю В. Лук'янова, в якій описується проблематика музики в контексті соціології П.А. Сорокіна. Специфіка творчих виявів С. Зажитька представлена у публікації Дзенислави Саф'ян.

Виділення не вирішених раніше частин загальної проблеми. Педагогічні напрацювання Євгена Станковича досі не здобували достатнього наукового висвітлення.

Мета статті полягає у дослідженні особливостей педагогічних принципів Євгена Станковича, а також в окресленні його впливу на становлення сучасної композиторської школи і розвиток музичного виконавства в Україні.

Виклад основного матеріалу. Творчий і педагогічний шляхи Євгена Федоровича Станковича $€$ двома гранями його діяльності, що нерозривно пов'язані та взаємодоповнюють одна іншу. Власні композиторські напрацювання митця впливають на формування тенденцій в українській музиці. Вони сприяють вихованню певної слухацької культури, призвичаюючи глядачів до сприйняття сучасного композиторського мислення. Враховуючи це, доречно окреслити загальні риси композиторського стилю Станковича перед тим, як перейти до його досягнень у педагогічній царині.

Він є майстром, який працює у всіх монументальних жанрах, робота над якими виступає наочним свідченням професійності композитора: опера, балети, симоронії, концерти, вокально-симфонічні твори та музика до кінострічок. Ю. Чекан зазначав про універсальність митця, який задає нові параметри для творчого розвитку національної композиторської школи: «Видатний композитор сучасності Євген Станкович, як уже зазначалося, - митець-універсал, без творів якого не можливо уявити нині українську музичну культуру. Наразі немає такої сфери в академічній музиці, у якій би композитор не сказав свого вагомого слова. Понад те, саме твори $Є$. Станковича фрормують конфрігурацію жанрового простору української музики останніх чотирьох десятиліть, визначають його пріоритетні напрями, відкривають нові й оновлюють відомі традиційні виміри» [5, с. 154-155].

Велику роль для розвитку сучасної інструментальної культури має Міжнародний інструментальний конкурс Євгена Станковича, в якому Євген
Федорович бере участь як голова журі. Головним засновником конкурсу є благодійний фронд «ВІВАТ АРТ», а співорганізаторами - Національна спілка композиторів України та Національний комітет музичної Ради / ЮНЕСКО. Брати в ньому участь можуть солісти та колективи віком від 5 до 32 років.

Творів Євген Федорович написав чимало, причому в їхній динаміці можна прослідкувати таку рису, як стильове різноманіття. Залежно від обраного жанру композитор дифреренціює виразні засоби, намагаючись дотримуватися кореляції між фрункціональним призначенням твору та шляхами досягнення художньої мети. Зауважимо, що для Станковича притаманне превалювання інструментальних творів, проте інтонаційний бік його музики тісно пов'язаний із фольклорним мелосом. Стильовий плюралізм композитора реалізується у написанні творів із яскравою ладовою природою, в розширеній тональності чи повністю витриманих у межах тональності, що зумовлюється жанром і призначенням.

Цей плюралізм реалізується й у педагогічній діяльності Євгена Станковича. Відсутність домінування у питанні спрямування творчості учнів його класу, можливість кожному писати в тому руслі, яке йому більше до душі, є основним методичним принципом Станковича. «Головне для композитора, на його думку, - професійність найвищого ґатунку; при цьому кожному дається максимальна свобода самореалізації. Профресор Є. Станкович цінує, оберігає і леліє неповторність кожного свого учня, не нав'язує нікому своєї думки чи готового рішення, навпаки - прагне розкрити своєрідність кожного» [5, с. 156]. Це висловлення демонструє провідний принцип композитора, якому він слідує у творчій діяльності, - свобода виявлення власних прагнень. ІІї Станкович повністю реалізує у викладанні. Це ставлення до студентів, як до рівних, у прагненні розкрити творчий потенціал.

Підтвердженням цього є теза А. Луніної, адресована характеристиці авторського підходу майстра: «Станкович ніколи не виступав і не виступає у музиці заумним і нудотним дидактиком. Він далекий від повчальності, навіть у творах із яскравою соціальною тематикою. Композитор тільки показує проблему, але не обговорює її і не наставляє на правильний шлях. Він виступає як коментатор, залишаючи за слухачем право самому доходити до істинного розуміння своїх епістол» [3, с. 40]. Ці ж риси стосуються і ставлення Станковича до учнів. Це коментування певних недоліків, окреслення проблемних моментів, що наявні у творах, проте не карколомна критика.

Існує тип викладачів-композиторів, для яких еталонною $є$ їхня власна творчість, тому й педагогічна справа орієнтована на те, щоб учні копіювали їхню манеру. Все ж інше сприймається як таке, що не відповідає профресійному рівню. Ця риса жод- 
ним чином не може асоціюватися із педагогічними підходами Станковича. Будучи учнем провідного композитора-класика української музичної культури Бориса Лятошинського, Євген Федорович успадкував від нього інтерес до жанрового різноманіття, пошуковий характер творчості, що реалізується через різні техніки композиції. Опора на фольклорні витоки була притаманна й творчим методам Б. Лятошинського.

у творах Станковича переплітаються об'єктивне та суб'єктивне начало, раціональність та емоційність, духовне та світське. Причому композитор поєднує ці діаметрально протилежні начала з великою майстерністю. У концепції мислителя П. Сорокіна музична практика розуміється як фрорма передачі інорормації у почуттєвій фрормі: «Музика $€$ другою основною фрормою символічних звукових провідників. Вона більше пристосована до об'єктивації і передачі почуттів, емоцій, настроїв або невловимих розумових станів, які не піддаються вербальному вираженню, тому вона найчастіше використовується для емоційної, ніж для інтелектуальної комунікації» [4, с. 209].

Користуючись запропонованим фрілософом поділом музики на ідеаціональний, ідеалістичний та чуттєвий типи, можна зазначити, що хорова музика Станковича відповідає третьому типові. Це музика, сповнена чуттєвим началом, яка вражає своєю красою та, подібно до середньовічної музики ідеаціонального типу, дозволяє стверджувати про високий ступінь однорідності суспільної свідомості. «Сорокін не відмовляє музичним творам XIX і XX століть у здатності гармонійно поєднувати «ідеаціональні цінності і чуттєву красу». Безсумнівно, що і в цей період творили композитори, чиї твори були позначені «дивовижним злиттям» ідеаціонального і чуттєвого стилів» [2, с. 124].

Проте, якщо говорити про учнів Станковича, то їхня творчість не може бути зведена до тих же знаменників, адже кожен із них демонструє зацікавленість у принципово різних композиторських стилях і методах розвитку музичного матеріалу. Серед його учнів варто згадати Людмилу Юріну, Сергія Зажитька, Дмитра Щирицю, Золтана Алмаші, Анну Рождественську та інших провідних композиторів. Колишні учні його класу мають різний творчий почерк. Дехто здебільшого орієнтований на візії постмодерного музичного письма, експериментальність та епатаж, як Сергій Зажитько. Інші ж більше орієнтуються на розвиток неоромантичного напряму (як Ганна Рождественська). Тобто не можна виділити єдину магістральну лінію розвитку майстерності випускників класу Є. Станковича. Скоріше кожен із композиторів віднайшов у роботі з викладачем те натхнення і підтримку, що дозволило розвивати інструментальну або вокальну-хорову майстерність, здійснювати епатажні пердорманси на сцені або дотримуватися академічної схеми у презентуванні творів. Кожен розвинув той напрям, що був близьким за його внутрішнім світовідчуттям.

Для творчості Станковича притаманна перевага інструментальних творів, проте це не заважає майстрові звертатися до хорового складу як в оперних творах, так і у тих, що призначені виключно для хору. Досить цікавим є те, що композитор використовує хор і у симсронічних творах. Причому хор може бути як одним з учасників, як у Симфонії № 3 «я стверджуюсь», яка виконується солістом, симфонічним оркестром і мішаним хором, так і основним учасником, як у Симфонії-Диптисі для хору а cappella. Якщо говорити про суто хорові твори композитора, то він пише чимало композицій для різних складів а capella: жіночих, чоловічих і мішаних колективів. Зокрема, у цій сорері виокремлюються твори, пов'язані 3 духовною тематикою: псалми для жіночого та чоловічого хору а cappella, Літургія та інші.

Інтерес до хорової сорери $€$ сутнісною рисою української композиторської школи, адже фрактично у кожного вітчизняного композитора був хоча б один хоровий твір. Ця ознака сформувалася внаслідок розвитку вітчизняної практики хорового духовного співу, яка, на відміну від суто інструментального, розвивалася безперервно. Ганна Рождественська (Кузіна) - випускниця профресора Станковича - часто обирає хоровий склад. У її творах неодноразово домінантною була саме духовна тематика. Так, у творі «Мій голос до Бога» для мішаного хору (Псалом № 76) використовується знаменний розспів. Ця характеристика наявна і у Літургії Святого Іоанна Златоустого для мішаного хору $€$. Станковича. Обидва твори виступають точкою перетину традиції духовного музикування та сучасного композиторського мислення.

Якщо говорити про характер тематизму, то у багатьох випадках мелодика тем Євгена Станковича демонструє зв'язок із народнопісенними витоками. Наприклад, у номері «Святий Боже» 3 Літургії тематичний матеріал проходить у високому регістрі в сопрано у більш швидкому темпі порівняно 3 початком Літургії, проступають інтонації, які нагадують веснянки. А. Волотка зазначає, що стосовно стилю $Є$. Станковича буде правильним зауваження про наявність у ньому фольклорних елементів. В його творах виявляються і елементи техніки сучасного письма. «Синтез фольклорних інтонацій та поліфонічних прийомів сучасної композиторської техніки - це те, що поєднує багатьох митців у трактуванні жанру духовного концерту» [1, с. 361].

Дійсно, подібні риси можна прослідкувати і у творчості деяких учнів композитора, які також звертаються до духовної тематики, здебільшого у творах, пов'язаних із вокальним началом. Так, у творі Ганни Рождественської "In memoriam” для 
баса, мішаного хору та симфронічного оркестру на тексти з Біблії також наявні елементи, що відсилають до народнопісенних витоків. Між симфронією-концертом для скрипки з оркестром Рождественської присутні риси, що споріднюють її 3 камерними симороніями Станковича.

У творчості деяких учнів розкриваються абсолютно інші виміри композиторського натхнення. Так, Сергій Зажитько розвиває музику експериментального характеру. Спектр творчих інтересів простягається від рок-стилістики, як у рок-альбомі «Двічі народжений», створеному у співавторстві 3 Сергієм Пілютиковим до елементів джазу та фрольклорних награвань у творі «Танцюється» для гобою та фрортепіано. Крім цього, у ранніх творах композитора (наприклад, «Ось так!» для фортепіано) інструмент застосовується в ударноперкусійній фрункції.

Гра на клавішах є скоріше виключенням, аніж правилом. Автор використовує корпус рояля, струни, деку як джерело звуку, яке видобувається за рахунок щипкових та ударних прийомів гри. У низці творів використовується принцип перформативності, адже часто Зажитько застосовує театралізовані фрорми, спрямовані на гру з публікою. Так, у творі «Пісня про головне» для скрипки, баяна, струнних і великого барабана та частина виконавців струнно-смичкової групи, яка не грає у певний момент часу, має вставати під час звучання твору і знаходитися стоячи, потім знову сідати для того, щоб зіграти частину своєї партії, і знову зводитися на ноги.

у «Присвяті Семюелу Бекету» для німого читця та контрабасу також наявні перформативні елементи. Твір сповнений епатажності, іронії, гротеску. «Для прослуховування твору потрібно вивільнити свідомість від класичної аудіальної підготовки, згребти у мішок свій слуховий багаж і не втрапляти в оману. Розпізнати світлу тінь читця можна у його контрабасовому дзеркалі: музична мова, яка не змовкає, справді відповідає людській мові: так само заїкається, шепоче, волає, співає»
[6]. Чимало елементів залишаються на розсуд виконавців, їм надається чимало свободи.

Висновки. Діяльність Євгена Станковича $€$ такою, що мала різні вектори свого спрямування. Композиторська справа та викладання стали сорерами, які тісно переплетені. Станкович вільно оперує засобами художнього вираження, що сформувалися упродовж останніх століть. Головним принципом творчої реалізації власних задумів і викладання $€$ свобода - можливість обирати будь-який жанр чи стильовий напрям, не маючи жодних перепон.

Його внесок як композитора не менше вплинув на композиторську національну школу, ніж його безпосередні здобутки на педагогічній ниві. Учні класу Євгена Станковича є композиторами, які працюють у різних стильових напрямах - від неоромантизму і неофольклоризму до джазу, року та перорормативних практик. Подібна широта уподобань сорормована завдяки плюралізму педагогічного підходу Євгена Станковича у викладацькій справі та підтримці талановитої молоді.

\section{БІБЛІОГРАФІЧНИЙ СПИСОК:}

1. Волотка А. Жанрово-виконавські аспекти хорового стилю Є. Станковича. Проблеми взаємодії мистецтва, педагогіки, теорії і практики освіти. 2014. Вип. 39. С. 353-363.

2. Лукьянов В.Г. Проблематика музыки в контексте социологии П.А. Сорокина. Вестник СанктПетербургского университета. Социология, 2015. № 4. C. 119-126.

3. Луніна А. Таїнство верлібру, або код-ейдос «послання» Євгена Станковича... Музика, 2012. № 5(388). С. 38-41.

4. Сорокин П.А. Человек. Цивилизация. Общество / общ. ред., сост. и предисл. А.Ю. Согомонова; пер. с англ. Москва : Политиздат, 1992. 543 с.

5. Чекан Ю.І. Євген Станкович: три штрихи до портрета. Часопис Національної музичної академії України імені П.І. Чайковського, 2013. № 4. С. $153-161$.

6. Сафр'ян Д. Слухати сучасну академічну музику. Сергій Зажитько: «Присвята Семюелу Бекету». URL: https://theclaquers.com/posts/3995. 